Meta

Journal des tradlucteurs

Translators' Journal

\title{
On the Translation of the Chinese Poetry into English
}

\section{Xin Ling}

Volume 34, numéro 2, juin 1989

URI : https://id.erudit.org/iderudit/003510ar

DOI : https://doi.org/10.7202/003510ar

Aller au sommaire du numéro

Éditeur(s)

Les Presses de l'Université de Montréal

ISSN

0026-0452 (imprimé)

1492-1421 (numérique)

Découvrir la revue

Citer cet article

Ling, X. (1989). On the Translation of the Chinese Poetry into English. Meta, 34(2), 259-267. https://doi.org/10.7202/003510ar d'utilisation que vous pouvez consulter en ligne.

https://apropos.erudit.org/fr/usagers/politique-dutilisation/ 


\title{
ON THE TRANSLATION OF THE CHINESE POETRY INTO ENGLISH
}

\author{
XIN LING \\ Huazhong Normal University, Wuhan, China
}

For a long time, the translatability regarding poetic works has been a heated argument in the world of literary translation. Much effort has been made by the translators of literary works in their attempt to introduce literature from one culture to another. Nevertheless, the results achieved have been controversial. The difficulties underlying the translation of literature, especially that of poetry, result not only from the appropriate rendering of the language in the text itself but also, more frequently, from the faithful maintenance of the literary style of the source language in the target language. It is exactly these difficulties that lead not a few people, who are concerned with literary translation, to believe that a full translation of literary works, and poetry in particular, is not only difficult but also almost impossible. The present paper is a tentative discussion about the difficulties in the English translations of Chinese classical poetry in terms of style by way of comparison.

Before this comparative study begins, it is necessary to make clear the general criteria for translation. In order to develop the scientific, economic and cultural flow between different countries, people, since ancient times, have been employing translation as an important tool for language communications. Regarding the quality of a translation, two points are held by the translation world as important : 1) faithfulness to the idea in the source language; 2) smoothness of the expression in the target language. Faithfulness requires that the translator should not only be loyal to the contents of the source language but also faithful to its styles, which include the language style, national style, the writer's individual writing style, the style of the particular age and the style of the literary form. While the translation is required to be as faithful to the original as possible, the language employed in the translation should also be elegant and smooth so that the translation can be understood by readers in another culture without any difficulty. However, this latter quality is often subject to the former - faithfulness - and is often relative as far as the extent of the is concerned.

In literary translation, especially in poetry translation, the criteria provide a great challenge. Poetry, as it is known to all, is an expression of the natural flow of the feelings experienced by the writer and is presented in such a written form that it often demands a certain metrical pattern, rhyme schemes and, more importantly, the artistic use of language. This is, without exception, also the case with classical Chinese poetry. In classical Chinese poetry, each particular kind of poem requires a particular form or pattern, often fixed and arbitrary. Each form, in turn, has many other kinds of variation. Furthermore, classical Chinese poems are usually characterized not only by the extremely concise language, with each word implying a particular semantic content, but also, very often, by the use of various rhetorical devices. These characteristics have certainly been an advantage for the Chinese poets to express their emotions in an elegant and effective way, but have led to tremendous difficulties for those attempting to translate the poems into another lan- 
guage while, at the same time, trying to keep the original form. A comparison of the following poem in the original with its English translation ${ }^{1}$ will demonstrate how much has been missing in the target language in spite of the efforts made by the translator. The poem is written by Du Fu (A.D. 712-770), a famous poet of the Tang Dynasty (A.D. 618-907).

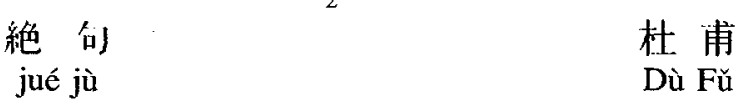

\begin{tabular}{|c|c|c|c|c|c|c|}
\hline $\begin{array}{l}\text { 兩 } \\
\text { liăng, } \\
\text { two }\end{array}$ & $\begin{array}{l}\text { 個 } \\
\text { gè } \\
\text { (n.m.w.)* }\end{array}$ & $\begin{array}{l}\text { 巔 } \\
\text { huáng } \\
\text { yellow }\end{array}$ & $\begin{array}{l}\text { 䳡 } \\
l i \\
\text { orioles }\end{array}$ & $\begin{array}{l}\text { 嶋 } \\
\text { ming } \\
\text { sing }\end{array}$ & $\begin{array}{l}\text { 翠 } \\
\text { cùi } \\
\text { green }\end{array}$ & $\begin{array}{l}\text { 柳 } \\
\text { liǔ } \\
\text { willow }\end{array}$ \\
\hline $\begin{array}{l}\overrightarrow{Y \bar{l}} \\
\text { one }\end{array}$ & $\begin{array}{l}\text { 行 } \\
\text { háng } \\
\text { team }\end{array}$ & $\begin{array}{l}\text { |'। } \\
\text { bái } \\
\text { white }\end{array}$ & $\begin{array}{l}\text { 鸜 } \\
l \grave{u} \\
\text { herons }\end{array}$ & $\begin{array}{l}\qquad \\
\text { shàng } \\
\text { (soar)up }\end{array}$ & $\begin{array}{l}\text { 青 } \\
\text { qing } \\
\text { blue }\end{array}$ & $\begin{array}{l}\text { 天 } \\
\text { tiān } \\
\text { sky }\end{array}$ \\
\hline $\begin{array}{l}\text { 窗 } \\
\text { chuāng } \\
\text { window }\end{array}$ & $\begin{array}{l}\text { 含 } \\
\text { hán } \\
\text { hold }\end{array}$ & $\begin{array}{l}\pi \bar{\pi} \\
x \bar{l} \\
\text { western }\end{array}$ & $\begin{array}{l}\text { 嶺 } \\
\text { ling } \\
\text { peak }\end{array}$ & $\begin{array}{l}\mp \\
\text { quiān } \\
\text { thousand }\end{array}$ & $\begin{array}{l}\text { 秋 } \\
q i \bar{u} \\
\text { year }\end{array}$ & $\begin{array}{l}\text { 雪 } \\
x u \check{~} \\
\text { snow }\end{array}$ \\
\hline $\begin{array}{l}\text { 閒 } \\
\text { mén } \\
\text { door }\end{array}$ & $\begin{array}{l}\text { 溞 } \\
p \bar{o} \\
\text { anchor }\end{array}$ & $\begin{array}{l}\text { 東 } \\
\text { dōng } \\
\text { eastern }\end{array}$ & $\begin{array}{l}\text { 兴 } \\
w u ́ \\
\text { Wu } \\
\text { kingdom) }\end{array}$ & $\begin{array}{l}\text { 萬 } \\
\text { wàn } \\
\text { ten thousa }\end{array}$ & $\begin{array}{l}\text { 里 } \\
l i \\
\text { ad (n.m.w.) }\end{array}$ & $\begin{array}{l}\text { 船 } \\
\text { chuán } \\
\text { junks }\end{array}$ \\
\hline
\end{tabular}

*n.m.w. - numeral measure word

The English version of the poem:

An Impromptu Verse $\mathrm{Du} \mathrm{Fu}$

A pair of orioles sing amid the willows green.

And up the sky a flock of herons white now soar.

Westward the snow-capped peaks are through my windows seen.

While junks from far-off Tung-wu lie beyond my door.

(Ts'ai, 51)

In the Chinese version of the poem two points are the most prominent: the fixed number of the words in each line and the strict antithesis of the sentences. The form of the poem is extremely neat, with each line having only seven characters or, simply, seven syllables. This neat form results from the deviations of the normal Chinese sentence order, which is partly due to

(1) the breaking of the subcategorical restrictions:

鳴 (ming, sing) is used as a transitive verb and is followed immediately by 椊柳 (cuililǐ, green willows) which denotes a place in the poem; 
(2) the breaking of the selectional co-occurrence of the semantic marker: 門 (mén, door) has normally the semantic marker of (-inanimate), (+ place) and (-causation), and, therefore, should not be used as the agent of the action "anchor" ;

(3) the use of topicalization:

The words 窗 (chuäng, window) and $\mu^{-1}$ (mén, door), though used as agents in their separate lines, actually indicate places. By placing the two words at the very beginnings of the lines, the poet provides the readers with an advantageous angle of viewpoint and, at the same time, directs their attention from the objects nearby to the scenery far away so as to achieve a vivid effect unique to moving pictures. But as it is noticeable in the English version, the two lines are quite different in the sentence order - from the far-off scenery to the objects nearby. Though this arrangement makes the sentences grammatically correct, a lot of beauty is lost through the change.

Thus by purposely violating the law of language, the poet $\mathrm{Du}$ Fu succeeded in placing each meaningful phrase in its appropriate place, foregrounding the idea through the use of antithesis and topicalization, thus endowing the poem with a unique beauty and a pleasant rhythmic effect. The following list of the semantic markers for each word shows how well each word in the odd lines is matched with its corresponding word in the even lines and how ingenious the poet was in arranging his words and ideas:

\begin{tabular}{|c|c|c|c|}
\hline 兩 two & 佔 (n.m.w.)* & 黃 yellow & 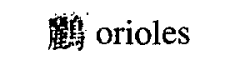 \\
\hline - one & 行 team & 白 white & 路 herons \\
\hline \multirow[t]{4}{*}{$\begin{array}{l}\text { [+ adjective }] \\
\text { [+ numeral }]\end{array}$} & $\begin{array}{l}{[+ \text { noun }]} \\
{[+ \text { n.m.w. }]^{*}}\end{array}$ & $\begin{array}{l}{[+ \text { adjective }]} \\
{[+ \text { color }]}\end{array}$ & $\begin{array}{l}\text { [+ noun] } \\
{[+ \text { animate }]} \\
{[+ \text { bird }]} \\
\text { [+ flying }] \\
{[+ \text { plural }]}\end{array}$ \\
\hline & 撨 sing & 翠 green & 柳 willow (1) \\
\hline & 上 soar & 青 blue & 天 sky (2) \\
\hline & $\begin{array}{l}{[+ \text { verb }]} \\
{[+ \text { transitive }]} \\
{[+ \text { action }]}\end{array}$ & $\begin{array}{l}{[+ \text { adjective }]} \\
{[+ \text { color }]}\end{array}$ & $\begin{array}{l}\text { [+ noun] } \\
\text { [+ place }] \\
\text { (1) }[+ \text { on earth }] \\
\text { (2) }[+ \text { in sky }]\end{array}$ \\
\hline 窗 window & 含 hold & 西 western & 嶺 peak \\
\hline 門 door & 论 anchor & 東 eastern & 参 Wu \\
\hline $\begin{array}{l}\text { [+ noun }] \\
{[- \text { inanimate }]} \\
{[+ \text { object }]} \\
{[+ \text { agent }]}\end{array}$ & $\begin{array}{l}{[+ \text { verb }]} \\
{[- \text { motion }]} \\
{[+- \text { object }]}\end{array}$ & $\begin{array}{l}\text { [+ adjective] } \\
{[+ \text { direction] }}\end{array}$ & $\begin{array}{l}{[+ \text { noun }]} \\
{[+ \text { place }]} \\
{[+ \text { remote }]}\end{array}$ \\
\hline
\end{tabular}




\begin{tabular}{|c|c|c|}
\hline$\mp$ thousand & 秋 year (1) & 雪 snow (1) \\
\hline 萬 thousand & 里 li (2) & 船 junk (2) \\
\hline $\begin{array}{l}{[+ \text { adjective }]} \\
{[+ \text { numeral }]}\end{array}$ & $\begin{array}{l}\text { [+ noun] } \\
\text { (1) }[+ \text { time }] \\
\text { (2) }[+ \text { space }]\end{array}$ & $\begin{array}{c}\text { [+ noun] } \\
{[+ \text { object }]} \\
\text { (1) }[- \text { motion }] \\
\text { (2) }[+ \text { motion }] \\
\text { (1) }[+ \text { remote }] \\
\text { (2) }[- \text { remote }]\end{array}$ \\
\hline
\end{tabular}

*n.m.w. - numeral measure word

In the series of antitheses here, the poet presented the readers with a unique picture of a beautiful early spring. The picture gives prominence to the different gay colors yellow, white, green and blue, and the combination of the opposite conceptions : motion $v s$. stillness, western vs. eastern, time $v s$. space, earthly beauty $v s$. heavenly joy... These carefully-juxtaposed phrases show not only the poet's mastery of the language but also the poet's ecstasy at seeing the amazing beauty of nature. Although the English version has supplied the rhyming scheme $a b a b$, which is absent in the original, it lacks the very uniqueness and the beauty of the original poem - the perfect union of form and content.

Besides the form, another difficulty in poetry translation is the choice of the appropriate words to convey the poet's implications. As we have noted before, almost every word in Chinese is loaded with substantial meaning, sometimes not only in terms of its literal meaning but also in terms of its connotation. However, for a translator with a Western cultural background, it is often difficult to arrive at the underlying meanings of the words used in the poem, or sometimes, even if he has grasped the words' underlying meanings, it is still not easy to express them fully and naturally without spoiling the form of the original poem. The poem below was written by Lu You (A.D. 1125-1210), a famous Chinese poet in the Song Dynasty (A.D. 960-1279), to express his deep regret to have to divorce his first wife Tan Wan, whom he still loved dearly during the later years of his life. ${ }^{3}$ The original poem in Chinese ${ }^{4}$ is as follows:

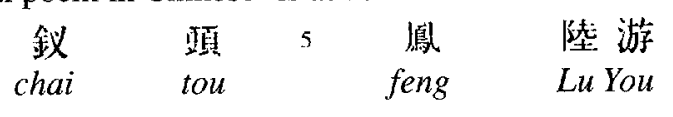

\begin{tabular}{|c|c|c|c|c|c|c|}
\hline $\begin{array}{l}\text { 紬. } \\
\text { hóng } \\
\text { red/pink }\end{array}$ & $\begin{array}{l}\text { sha } \\
s \bar{u} \\
\text { soft }\end{array}$ & $\begin{array}{l}\text { 手 } \\
\text { shǒu } \\
\text { hand }\end{array}$ & & & & \\
\hline $\begin{array}{l}\text { 黄 } \\
\text { huáng } \\
\text { yellow }\end{array}$ & $\begin{array}{l}\text { 䐯 } \\
\text { téng } \\
\text { (a brand) }\end{array}$ & 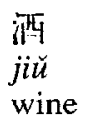 & & & & \\
\hline $\begin{array}{l}\text { 满 } \\
\text { măn } \\
\text { whole }\end{array}$ & $\begin{array}{l}\text { 城 } \\
\text { chéng } \\
\text { town }\end{array}$ & $\begin{array}{l}\text { 倠 } \\
\text { chün } \\
\text { spring }\end{array}$ & $\begin{array}{l}\text { 色 } \\
\text { sè } \\
\text { color }\end{array}$ & $\begin{array}{l}\text { pols } \\
\text { palace }\end{array}$ & $\begin{array}{l}\text { 跣 } \\
\text { qiâng } \\
\text { wall }\end{array}$ & $\begin{array}{l}\text { 柳了 } \\
\text { liǔ } \\
\text { willow }\end{array}$ \\
\hline $\begin{array}{l}\text { 東 } \\
\text { dōng } \\
\text { east }\end{array}$ & $\begin{array}{l}\text { 䖝 } \\
\text { féng } \\
\text { wind }\end{array}$ & $\begin{array}{l}\text { 恶 } \\
\grave{e} \\
\text { fierce }\end{array}$ & & & & \\
\hline
\end{tabular}




\begin{tabular}{|c|c|c|c|}
\hline $\begin{array}{l}\text { 歡 } \\
\text { huán } \\
\text { joyous }\end{array}$ & $\begin{array}{l}\text { 情 } \\
\text { qing } \\
\text { feeling }\end{array}$ & $\begin{array}{l}\text { 薄 } \\
\text { báo } \\
\text { frail }\end{array}$ & \\
\hline $\begin{array}{ll}\text { 一 } & \text { 懷 } \\
y \bar{l} & \text { huái } \\
\text { a bosom }\end{array}$ & $\begin{array}{l}\text { 愁 } \\
\text { chóu } \\
\text { sad }\end{array}$ & $\begin{array}{l}\text { 緒 } \\
x \grave{u} \\
\text { emotion }\end{array}$ & \\
\hline $\begin{array}{l}\text { 幾 } \\
j \grave{l} \\
\text { several }\end{array}$ & $\begin{array}{l}\text { 4 } \\
\text { nián } \\
\text { years }\end{array}$ & $\begin{array}{l}\text { 離 } \\
n i \\
\text { lonely }\end{array}$ & $\begin{array}{l}\text { 菜 } \\
\text { suǒ } \\
\text { solicitude }\end{array}$ \\
\hline $\begin{array}{l}\text { 鍇 } \\
c u \dot{o} \\
\text { wrong }\end{array}$ & $\begin{array}{l}\text { 䱶 } \\
\text { cuò } \\
\text { wrong }\end{array}$ & $\begin{array}{l}\text { 辞 } \\
\text { cuò } \\
\text { wrong }\end{array}$ & \\
\hline $\begin{array}{l}\text { 春 } \\
\text { chún } \\
\text { spring }\end{array}$ & $\begin{array}{l}\text { 邚 } \\
r u ́ \\
\text { (be) lik }\end{array}$ & $\begin{array}{l}\text { 焦 } \\
\text { jiù } \\
\text { old }\end{array}$ & \\
\hline
\end{tabular}

\begin{tabular}{|c|c|c|c|c|c|c|}
\hline $\begin{array}{l}\hat{\wedge} \\
\text { rén } \\
\text { man }\end{array}$ & $\begin{array}{l}\text { : } \\
\text { kìng } \\
\text { eōnpty }\end{array}$ & $\begin{array}{l}\text { 霞 } \\
\text { shou } \\
\text { thin }\end{array}$ & & & & \\
\hline $\begin{array}{l}\text { 淡 } \\
\text { nèi } \\
\text { tear }\end{array}$ & $\begin{array}{l}\text { 痃 } \\
\text { héng } \\
\text { stains }\end{array}$ & $\begin{array}{l}\text { 綡. } \\
\text { hóng } \\
\text { red }\end{array}$ & $\begin{array}{l}\text { 浊 } \\
y \underline{1} \\
\text { wet }\end{array}$ & $\begin{array}{l}\text { 鮫 } \\
\text { jiāo } \\
\text { (a kind) }\end{array}$ & $\begin{array}{l}\text { 維 } \\
\text { xiāo } \\
\text { silk }\end{array}$ & $\begin{array}{l}\text { 透 } \\
\text { tòu } \\
\text { through }\end{array}$ \\
\hline $\begin{array}{l}\text { 桃 } \\
\text { táo } \\
\text { peach }\end{array}$ & $\begin{array}{l}\text { 花 } \\
\text { huã } \\
\text { blossoms }\end{array}$ & $\begin{array}{l}\text { 落 } \\
\text { luò } \\
\text { fall }\end{array}$ & & & & \\
\hline $\begin{array}{l}||: \mid \\
\text { xián } \\
\text { vacant }\end{array}$ & $\begin{array}{l}\text { 池 } \\
\text { chi } \\
\text { pond }\end{array}$ & $\begin{array}{l}\text { 葆 } \\
\text { gé } \\
\text { pavilion }\end{array}$ & & & & \\
\hline $\begin{array}{l}\text { 山 } \\
\text { shān } \\
\text { mountain }\end{array}$ & $\begin{array}{l}\text { 㗐 } \\
\text { méng } \\
\text { oath }\end{array}$ & $\begin{array}{l}\text { 蜼 } \\
s \bar{u} i \\
\text { though }\end{array}$ & $\begin{array}{l}\text { 在 } \\
z \grave{a} i \\
\text { remain }\end{array}$ & & & \\
\hline $\begin{array}{l}\text { 錳 } \\
j \text { jin } \\
\text { silken }\end{array}$ & $\begin{array}{l}\text { 暃 } \\
\text { sh } \\
\text { letter }\end{array}$ & $\begin{array}{l}\text { 﨡: } \\
\text { nán } \\
\text { hard }\end{array}$ & $\begin{array}{l}\bar{a} \bar{E} \\
\text { tuō } \\
\text { trust }\end{array}$ & & & \\
\hline $\begin{array}{l}\text { 莫 } \\
\text { mò } \\
\text { no no }\end{array}$ & $\begin{array}{l}\text { 莫 } \\
m o ̀ \\
\text { no }\end{array}$ & $\begin{array}{l}\text { 莫 } \\
\text { mò }\end{array}$ & & & & \\
\hline
\end{tabular}

(Ayling/Mackintosh, 156) 
The English version of the poem:

Ch'ai T'ou Feng Lu You

Crisp pink short-bread,

A flask of yellow wine,

The city bright with spring, on palace walls a willow line.

An east wind, a fierce wind

Has worn the rapture fine;

My heart is bound with sorrow round:

Parted, the many years too long;

How wrong it was, how wrong!

Spring's the same as ever,

Vain longings waste and wear;

My silken handkerchief is soaked, there's blood in every tear.

Peach blossom scatters round

The lake and buildings bare.

Though solemn oath still binds us both

It's hard to trust a message, so

It's No! For ever No!

(Ayling/Mackintosh, 157)

Generally speaking, the poem is well translated. It is obvious that the translator has taken much thought to maintain the form of the original and has done his best to convey the sad emotions in the poem by combining the literal and the figurative translation methods. But as far as some of the dictions are concerned, the results are not altogether satisfactory. The first line slender hand, and a kind of food as understood by the translators. ${ }^{6}$ According to the story, $\mathrm{Lu}$ You happened to meet his divorced wife Tang Wan when he was on a spring outing in a garden. Tang and her new husband invited Lu to a dinner and she poured wine for Lu to his wine cup. Though face to face with the lady he still loved, Lu was unable to express his regret and love for her. After they parted, Lu snatched a brush and finished the improvised poem at one go on the rockery wall in the garden to express his deep regret and sorrow. It is said that when Tang Wan saw the poem on the wall later, she was so sad and melancholy that she died not long after. So here, most probably the poet is referring to the lady's pink, tender hand, which actually suggests the lady herself.

In the fourth and fifth lines in both stanzas one and two, there are four parallel phrases presenting contradictory ideas:

$\begin{array}{ll}\text { 東風惡 } & \text { the east wind }{ }^{7} \text { (is) fierce } \\ \text { 歡情溥 } & \text { the joy (is) frail } \\ \text { 桃花落 } & \text { the peach blossoms (are) falling } \\ \text { 閒池閣 the pond and the buildings (are) vacant }\end{array}$

From the literal translations above, it is noticeable that all the nouns in these phrases imply good connotations, but the poet made a sudden turn of his thought and used the words with unpleasant connotations to qualify the nouns. These parallel positions of the phrases with pleasant $v s$. unpleasant connotations reveal the poet's complicated feelings: he loved the lady but divorced her against his own will and could never retrieve his great error - he had lost her forever. Yet this great effect, achieved by using the words marked 
semantically with opposite qualities, is not as prominent in the English version as in the original.

The second line in the second stanza seems to be misinterpreted. In 人空㒛 here, 人 certainly refers to the poet himself, 䇥 (empty) can mean "lonely" and 馊 is "thin." From the background of the poem it is reasonable to infer that the poet has been tortured all day long by the regret and his vain love for the lady, and he is now a changed person, lonely and thin. In contrast to the sad state in himself, the spring is still as gay and exuberant as ever. Here the poet sees the eternity of nature on the one hand, and the mortality of human beings on the other, and he expressed his depressed mentality quite effectively by contrasting nature and human beings concerning their unchanging and changing natures.

Also worthy of attention are some of the words used by the poet, which have a typical Chinese cultural reference. Such words often pose greater difficulties for poetry translators unless detailed explanations are provided at the expense of the neatness of the form of the poetry and the conciseness of its expression. For the meanings of these words in Chinese are backed up with the Chinese culture and are quite vivid and connotative to a Chinese. Yet once they are translated literally into another language, the readers of the other language often fail to acquire the same understandings of the words as the a Chinese do when appreciating the poem in its original. The words selected here from the original poem and the English version accompanied by their connotative meanings can best prove this point. Here E.V. stands for the English version provided by the translator and C.B. for the Chinese encyclopedic background.

池 (chí)

E.V.: lake

C.B.: a pond in a garden with carps, or golden fish, water plants such as lotus flowers or water lilies, sometimes also with rockeries in the middle. It is often surrounded by willow trees dangling their long, flexible branches.

閣 (gé)

E.V.: building

C.B.: a pavilion-like wooden tower of the traditional Chinese style, with a top in the middle of the sloping roof, upturned eaves, green or yellow glazed tiles and big wooden columns painted red, and here standing by the pond in a park.

山盟 (shān méng)

E.V.: solemn oath

C.B.: the oath taken before mountains. The complete phrase is 11.1 望海誓, the oath taken in front of the mountains and seas, usually by young lovers in old days, in order to show their never-broken love and their unswerving loyalty to each other. The lovers choose the mountains and seas as the witnesses of their pledge because the mountains and seas, as part of nature, are eternal and imperishable, compared with the transient life of human beings. However, the use of the phrase here does not necessarily mean that $\mathrm{Lu}$ You took the oath with his lover before a mountain.

錦書 (jin $s h \bar{u})$

E.V.: message

C.B.: message written on a piece of silk. The origin of the phrase can be traced back to the ancient times of China when people had to use cloth or silk as their writing material before the invention and the wide-use of paper. Though later silk was still used by some people, especially by emperors for their imperial edicts, it was used mainly to show sincerity or solemnity. Nowadays, some traditional Chinese painters and calligraphers may still use it as a writing material for a special style. But the phrase has stayed in the vocabulary to mean "letter" in literary language. 
All this encyclopedic background is certainly absent in Western cultures and therefore undoubtedly sets up a barrier for the translators to convey fully both the words' literal meanings and their associative implications to English readers. The result is that by reading the poem in translation, the readers receive only the surface meanings and general ideas of the poem but really miss the chance to appreciate its beauty and its underlying messages, endeavored by the poet, as a whole.

Another typical thetorical device used by the Chinese poets is repetition, the purpose of which is to intensify the idea or emotion of the poet. In the poem by $\mathrm{Lu}$ You, each of the stanzas ends with the repetition of one word. In the first place, this parallel repetition completes the neatness of the poem's form and, at the same time, it lays emphasis on the poet's feeling of remorse. By repeating the word 錯 (cuo) three times in succession, the poet is actually crying to himself what an irretrievable mistake he has made in divorcing his wife in order to show obedience to his mother. The second repetition here is 莫 $(m \dot{o})$, and it is also repeated three times. The literal meaning of this word is "no." But from the context and the background of the poem, the word here implies the poet's entreaty to himself that the reality is so harsh and painful that he can no longer bear to think of it and so it is better "No more mentioning of the sad fact, no more !" While in the original poem each stanza is brought to an end with only the same three words, and both of the words 錯 (cuò) and 莫 (mò) have a fourth tone, which sounds quite forceful and definite, the English counterpart has six words and five words separately for the endings of the two stanzas. Although the translator has tried to maintain the strong effect of the original by repeating the ideas of "wrong" and "no" twice, the English version still lacks the definiteness and strength in a certain sense.

Indeed, most of the discrepancies discussed above have resulted from the great differences in the language systems of Chinese and English. As a typical isolating language, Chinese employs no articles, auxiliaries, tense markers and it has very limited prepositions. These characteristics distinguish Chinese as a language which is at once compact and expressive. Each word plays an indispensable part both in syntactic structures and semantic aspect. Compared with the wording of common speech and writing, the language used in poetry, especially that in traditional style, is even more succinct and terse. It is exactly this unique language style that contributes to the literary works the special qualities of elegance, conciseness and refinement. Once the poem typical of this style is turned into a language which calls for quite different language structures, much of the natural beauty of the original work will be lost in the process of translation.

Though the translators of Chinese poetry should be fully aware of the great difficulties before them, this is not to say that we should put an end to the efforts made thus far for the literature exchange between different cultures. On the contrary, it is this understanding of the differences in different languages that will further facilitate the acceleration of cultural contact between China and the rest of the world, which, in turn, will result in a deeper appreciation of Chinese literature, a treasure among the world's best.

\section{ACKNOWLEDGEMENT}

I owe my gratitude to Dr. Marvin K. Ching for his patience in reading this paper and giving me valuable suggestions. 
Notes

1. For the benefit of comparison, I supplied Chinese pinyin and an English literal meaning (without any grammatical markers) for each of the Chinese characters in the poem.

2. A kind of tune for Chinese classical poems.

3. He was forced to divorce Tang Wan because his mother didn't like her. In old China, children had to listen to their parents to show filial obedience.

4. I supplied Chinese pinyin and an English literal meaning for each word in the original.

5. A tune for Chinese classical poems.

6. At page 241, Appendix I, Chinese Lyrics, the translators explained:

Verse 1, line 1, This opening line can be variously translated. The meaning chosen here for the Chinese words "Red (or pink) flak (or crisp) hands" is that they refer to the northern short-bread, shaped in the making to look like a man's hand.

7. In Chinese culture, it is the east wind that brings spring - the symbol of life - - to the earth.

\section{WORKS CITED}

AYLING, Alan and Duncan MACKINTOSH (1965) : Chinese Lyrics, Nashville, Vanderbilt. CHEN, Yugang (1985) : A Brief History of the Chinese Literature, Shanxi, China, People's P.

CHING, Marvin K., Michael C. HALEY, and Ronald F. LUNSFORD, eds. (1980) : Linguistic Perspective on Literature, London, Routledge \& Kegan Paul.

FREEMAN, Donald C., ed. (1981): Essays in Modern Stylistics, New York, Methuen \& Co.

TS'AI, T'ing-kan (1969) : Chinese Poems in English Rhyme, New York, Greenwood. 